\title{
Negative Inotropic and Chronotropic Effects of Phenolic Fraction from Cynodon dactylon (linn) on Isolated Perfused Frog Heart
}

\author{
M. M. Shabi ${ }^{1 *}$, C. David Raj ${ }^{2}$, C. Sasikala ${ }^{3}$, K. Gayathri ${ }^{2}$, and J. Joseph ${ }^{1}$ \\ ${ }^{1}$ Department of Pharmacology, Amrita School of Pharmacy, Amrita Institute of Medical Science \\ (AIMS), Amrita Vishwa Vidyapeetham University, Kochi-682041, Kerala, India \\ ${ }^{2}$ Centre for Advanced Research in Indian System of Medicine (CARISM), SASTRA University, \\ Thanjavur-613 402, Tamil Nadu, India \\ ${ }^{3}$ Masterskill University College of Health Sciences, G-8, Jalan Kemacahya, Batu 943200 Cheras, \\ Selangor, Malaysia
}

Received4 September 2011, accepted in final revised form 26 May 2012

\begin{abstract}
Cynodon dactylon (L.) Pers belongs to the family Poaceae is a grass native to North Africa, Asia and Australia and southern Europe. The phenolic fraction of Cynodon dactylon (Linn) (CDP) was evaluated for its cardio-protective activity using isolated frog's heart perfusion method. The negative inotropic and chronotropic activities were recorded using kymograph. The CDP produced negative inotropic and chronotropic actions on isolated frog heart. The pharmacological effect was selectively inhibited by atropine indicating that these might have been mediated through muscarinic receptor.
\end{abstract}

Keywords: Cynodon dactylon; Hydroquinone; GC-MS; Inotropic; Chronotropic

(c) 2012 JSR Publications. ISSN: 2070-0237 (Print); 2070-0245 (Online). All rights reserved.

doi: http://dx.doi.org/10.3329/jsr.v4i3.8549 $\quad$ J. Sci. Res. 4 (3), 657-663 (2012)

\section{Introduction}

Cynodon dactylon (L.) Pers belongs to the family Poaceae is a grass native to North Africa, Asia and Australia and southern Europe. It has been used to treat urinary tract infection, calculi and prostatitis. The plant is astringent, sweet, cooling, demulcent, suppurative, haemostatic, depurative, vulnerary, constipating, diuretics and cardio-tonic [1].

Various phyto-constituents of Cynodon dactylon are beta sitosterol, beta-carotene, vitamin C, palmitic acid, triterpenoids, alkaloids like ergonovine and ergonovivine, ferulic acid, syringic acid, vanillic acid and p-coumaric acid, furfural, glucose, fructose [2]. Others include $\beta$-sitosterol, triterpenoids, arundoin, friedelin, selenium, p-hydroxy benzoic acid and o-hydroxyphenyl acetic acids, cyanogenic heteroside, cyanogenic glucoside-

\footnotetext{
*Corresponding author: sugindavid@yahoo.com
} 
triglochinin, furfural, furfural alcohol, phenyl acetaldehyde, acetic acid, phytol, $\beta$-ionone, mono and oligosaccharides, lignin, hydrocarbons (tritriaconate) esters, eicosanoic and docosanoic acids, free alcohol, free aldehydes (hexadecanal) and free acids (hexadecanoic acid) (surface cuticular wax), flavone like apigenin, luteolin, flavone glycosides-orientin (8-C- $\beta$-D-glycosyl luteolin), vitexin (8-C- $\beta$-D-glucosyl epigenin), iso-orientin (6-C- $\beta$-D glycosyl luteolin) and iso-vitexin-(6-C- $\beta$-D-glucosyl epigenin) [3].

Various pharmacological activities includes, antibiotic [4], has been reported earlier. The herb is commonly used in chronic diarrhoea and dysentery, epilepsy and hysteria, in catarrhal and ophthalmia [5]. Other pharmacological activities include coagulant [5], antimicrobial and antiviral activity [6], anti-cancer [7,8] anti-inflammatory, anti-dysentery [9], anti-diabetic [10], immunomodulatory [11] diuretic [12], cardiotonic [13], styptic, hematuria and hemorrhoids.

\section{Experimental}

\subsection{Plant}

The whole plant of Cynodon dactylon were collected from Kandarvakottai, Pudukkottai district, Tamilnadu, India and dried under shade and coarsely powdered. The plant material was identified and authenticated at Centre for Advanced Research in Indian System of Medicine (CARISM), SASTRA University, Thanjavur, Tamilnadu, India and the specimen of the same is maintained.

\subsection{Preparation of phenolic fraction}

Accurately 5.0 gm of dry plant was weighed in a beaker. To this $125 \mathrm{ml}$ of $1 \mathrm{~N} \mathrm{HCl}$ was added. The mixture was soaked and maintained at $50^{\circ} \mathrm{C}$ for 30 minutes and at room temperature for 2 hours. The extract was filtered. To the filtrate, $50 \mathrm{ml}$ of ether was added. The ether fraction was separated and allowed to evaporate. The concentrated fraction CDP obtained was used for the present study. The yield of fraction was calculated as $1 \% \mathrm{w} / \mathrm{w}$.

\subsection{Chemicals used}

Atropine was purchased from Sigma-Aldrich, St. Louis, USA. Other chemicals such as Sodium chloride $(\mathrm{NaCl})$, Potassium chloride $(\mathrm{KCl})$ Calcium chloride $\left(\mathrm{CaCl}_{2}\right)$, Sodium bicarbonate $\left(\mathrm{NaHCO}_{3}\right)$, Sodium dihydrogen phosphate $\left(\mathrm{NaH}_{2} \mathrm{PO}_{4}\right)$, Glucose were procured from Hi-Media laboratory Pvt. Ltd, Mumbai, India.

\subsection{Preparation of atropine}

A stock solution of $1 \mathrm{mg} / \mathrm{ml}$ was prepared using frog ringer solution. The following working concentrations were from the stock: $50 \mu \mathrm{g} / \mathrm{ml}$ and $100 \mu \mathrm{g} / \mathrm{ml}$ of this concentration were added as muscranic antagonist against CDP. 


\subsection{Preparation of drugs for pharmacological activity}

$10 \mathrm{mg}$ of CDP was dissolved in $1.0 \mathrm{ml}$ of Frog Ringer's solution. A stock solution of 10 $\mathrm{mg} / \mathrm{ml}$ was prepared with of frog ringer's solution. The following working concentrations were used from the stock: $1 \mathrm{mg} / 0.1 \mathrm{ml}$ and $1 \mathrm{mg} / 0.2 \mathrm{ml}$ of this concentration were added.

\subsection{Animal preparation}

An average sized frog was pithed and destroyed by passing a stiletto through the occipitoatlantic junction without causing any injury to its heart and associated blood vessels. The anterior chest wall was opened and a pericardiectomy was performed to expose the heart. The one end of the aorta, inferior vena cava was identified. A small cut inferior vena cava and a Syme's cannula was inserted towards the heart. A steady flow of the perfusion FrogRinger solution containing oxygenated, fluid of the following composition: $\mathrm{NaCl} 6.5, \mathrm{KCl}$ $0.14, \mathrm{CaCl}_{2}$ 0.12, and $\mathrm{NaHCO}_{3} 0.2, \mathrm{NaH}_{2} \mathrm{PO}_{4} 0.01$, Glucose 2.0 in gram per litre and the $\mathrm{pH}$ was adjusted to 7.20 by adding $\mathrm{Na}_{2} \mathrm{HPO}_{4}$ [14]. It was perfused through this cannula and there was an opening in the cannula through which drugs could be injected by pushing a capillary tube attached to a syringe through an injection needle. A very thin hook was attached to the apex of beating heart, which was tied with a cotton thread. The other end of the thread was attached with the Starling heart lever so that the movements of the beating of the heart could be recorded on a smoked paper of a kymographic drum. The force of contraction was recorded and the rate of contraction was counted and tabulated [15]. All animal experimentations were carried out with the guidelines of Institutional Animal Ethics Committee (IAEC).

\subsection{Statistical analysis}

Values were represented as Mean \pm SE. Significant difference was calculated using one way Analysis of Variance (ANOVA) using Duncan multiple range test. Values not sharing common signs were differ significantly at $\mathrm{p}<0.05$.

\section{Results and Discussion}

The inotropic and chronotropic effects of isolated heart were recorded from apex of beating heart connected to a starling heart lever on kymograph paper. The normal rate of contraction of isolated heart was recorded after stabilization for 15 minutes. The different doses $2 \mathrm{mg}$ and $4 \mathrm{mg}$ of phenolic fraction of CDP were injected directly to the isolated heart along with perfusion. The graded doses of CDP decreased the cardiac flow rate, heart rate and force of contraction. (Table 1 and Fig.1). However, the maximum response was produced by $4 \mathrm{mg}$ of CDP. Before adding CDP to the perfusate, atropine was added at the dose of 50 and $100 \mu \mathrm{g}$ followed by CDP (2 mg).The CDP (2 mg) was partially blocked by $50 \mu \mathrm{g}$ of atropine and fully blocked by $100 \mu \mathrm{g}$. The responses observed with 2 
mg of the CDP after administration of the antagonists are shown in Table 1 and Fig 1. Contractility was measured as the mean height in mm of 4 cardiac contractions spikes and heart rate as the number of beats per min. In our previous study, GC-MS analysis of CDP revealed the presence of various compounds and it contains hydroquinine as the major compounds [16].

Table 1. Effect of phenolic fraction from Cynodon dactylon on flow rate, heart rate and force of contraction in frog heart.

\begin{tabular}{clccc}
\hline Sl. No. & Drugs & $\begin{array}{c}\text { Flow volume } \\
(\mathrm{ml} / \mathrm{min})\end{array}$ & $\begin{array}{c}\text { Heart rate } \\
(\text { Beats/min })\end{array}$ & $\begin{array}{c}\text { Amplitude } \\
(\mathrm{mm})\end{array}$ \\
\hline 1 & Baseline & $15.0 \pm 2.5^{\mathrm{c}}$ & $72.0 \pm 2.3^{\mathrm{b}}$ & $16.0 \pm 1.3^{\mathrm{b}}$ \\
2 & CDP 2 mg & $10.0 \pm 2.1 \mathrm{~b}^{*}$ & $24.0 \pm 1.3^{\mathrm{a}^{*}}$ & $2.0 \pm 0.3^{\mathrm{a}^{*}}$ \\
3 & CDP $4 \mathrm{mg}$ & $7.8 \pm 1.2^{\mathrm{a}}$ & $15.0 \pm 3.2^{\mathrm{a}}$ & $1.0 \pm 0.2^{\mathrm{a}}$ \\
4 & Atropine $50 \mu \mathrm{l}+\mathrm{CDP} 2 \mathrm{mg}$ & $11.0 \pm 1.3^{*}$ & $60.0 \pm 4.6^{*}$ & $5.0 \pm 0.6^{* *}$ \\
5 & Atropine $100 \mu \mathrm{l}+\mathrm{CDP} 2 \mathrm{mg}$ & $13.0 \pm 2.1^{* *}$ & $67.0 \pm 5.2^{* *}$ & $12.0 \pm 1.3^{* * *}$ \\
\hline
\end{tabular}

Values are mean \pm SE $(n=6)$. Significant difference is calculated using one way ANOVA using Duncan multiple range test. Values not sharing common signs are differ significantly at $p<0.05$. a,b,c - significant difference between sl. no. 1, 2 and 3, whereas, *, **, *** denote significant difference between sl.no. 2, 4 and 5 , respectively.
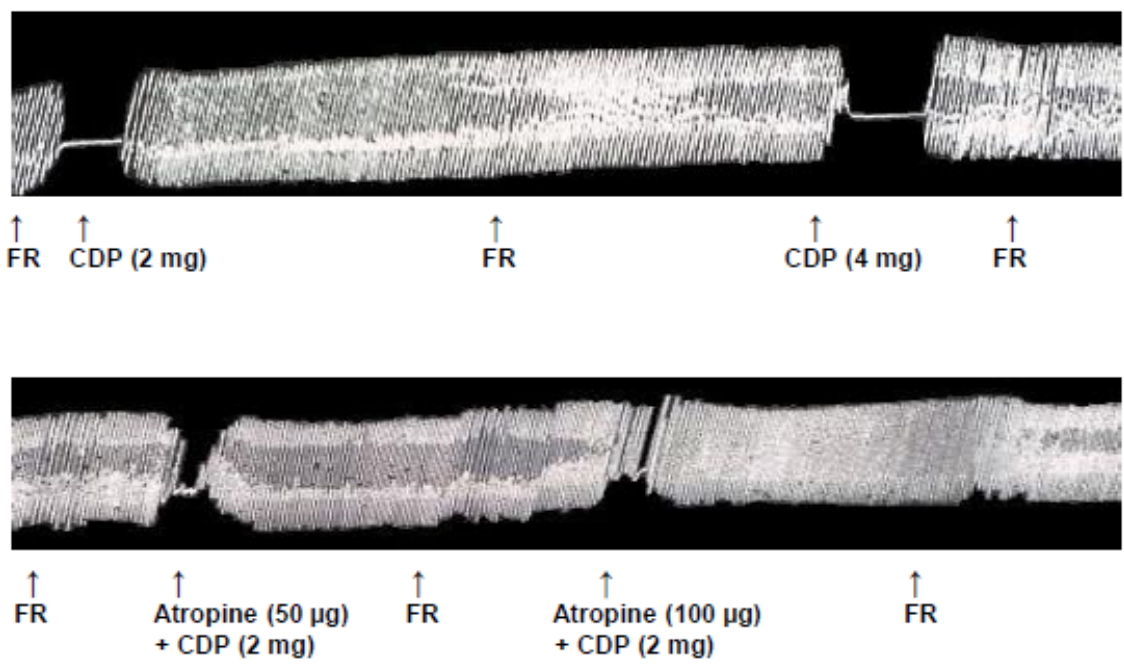

Fig. 1. Effect of phenolic fraction from Cynodon dactylon on isolated frog heart in the presence and absence of atropine. FR- Frog ringer solution, Base line stabilization time: $15 \mathrm{~min}$, Action of drug contact time: $1 \mathrm{~min}$, Drum rotation speed: $0.25 \mathrm{~mm} / \mathrm{second}$. 
In our present study, CDP fraction produced a negative inotropic effect on the myocardium. The cause of the effect is attributed to the shortened action potential [17]. The effect of CDP may also be mediated via stimulation of nitric oxide synthase (NOS). NOS inhibitors may prevent the negative chronotropic effect of CDP on spontaneously beating cardiomyocytes and suppress the inhibition of the L-type calcium current (ICa) by CDP in sinoatrial myocytes. This pathway may be relevant not only to the chronotropic effect of CDP but also to its inotropic effect, because CDP, NO, and cGMP regulate the force of contraction and ICa in the cardiac ventricle [18, 19].

Vasorelaxation is caused by three different mediators that includes, $\beta$-receptor antagonist, cholinergic receptor agonist and Endothelium derived relaxing factor (EDRF). Findings of the present research have revealed that the CDP fraction is able to act as a cholinergic receptor agonist thereby, able to cause vasorelaxation [20]. In order to evaluate whether the compounds present in CDP are responsible for the vasorelaxation, GC-MS analysis of CDP was performed which showed the presence of hydroquinone as a major compound [16]. Furchgott, [21] has explained that hydroquinone is able to inhibit EDRF and NO based relaxation in vascular smooth muscle. The mechanism of action of hydroquinone based inhibition of NO is either by acting as a free radical scavenger [22] or as a generator of superoxide anion [23]. Adrian et al., [24] have explained that hydroquinone is able to inhibit the NO dependent vasorelaxation. These findings reveal that CDP contains hydroquinone as the major compound, does not exhibit the vasorelaxation through NO. Richard et al., [25] have reported that vasorelaxation caused by EDRF is inhibited by left atrial injection of hydroquinone. They have also added the vasoconstriction caused by vasopressin was increased by hydroquinone.

We found that CDP have effect on the muscarinic agonist in isolated frog myocytes, In the presence of atropine CDP is not able to produce negative inotropic and negative chronotropic effect. In addition, these compounds have no beta-adrenergic stimulation or beta-adrenergic blocker. The CDP action is same like acetylcholine (Ach). Alfonsina [26] demonstrated that, well-known negative inotropism induced by Acetylcholine [20], a biphasic inotropic response to exogenous ACh has been sporadically reported in both amphibian and mammalian hearts [27, 28]. More recent studies showed that the AChstimulated isolated rabbit heart releases nitric oxide (NO) [29]. ACh affects myocardial contractility via an NO signal transduction pathway. Thus studies related with the response of endocardial endothelium to CDP conducted in the whole working cardiac pump might provide more reliable information on the biphasic inotropic response sporadically found in amphibian hearts. We conclude that in an isolated and perfused frog's heart, CDP produces a negative chrnotropic and inotropic effects which are mediated by muscarinic receptor. This statement further confirms that the activity of CDP extract might be due to the other receptors. 


\section{Conclusion}

The phenolic fraction of Cynodon dactylon exhibits negative inotropic and negative chronotropic activity. Moreover, the mechanism of action of the fraction is evaluated as muscarinic receptor antagonist and might be due to the presence of hydroquninone as the major compound. In future, the major compound of the fraction should be isolated and compared with the standard hydroquinone.

\section{Acknowledgements}

The authors are grateful to Prof. R. Sethuraman, Vice-Chancellor, SASTRA and his able administrative colleagues for allowing us to complete this work.

\section{References}

1. L. D. Kapoor, Handbook of Ayurvedic Medicinal plants (CRC Press, Baton Rouge, 2000).

2. S. Ravindra, Medicinal plants of India an Encyclopedia (Daya Publishing House, Delhi, 2003)

3. K. V. Billore, M. B. Yelne, T. J. Dennis, and B. G. Chaudhari, Database on medicinal plants used in Ayurveda (Central Council for Research in Ayurveda and Siddha, 2000)

4. J. V. Bhat and R. Broker, J. Sci. Indus. Res. Sect. B 12, 540 (1953).

5. R. N. Chopra, Glossary of Indian Medicinal plants (CSRI, New Delhi, 1956).

6. M. L. Dhar, M. M. Dhar, B. N. Dhawan, B. N. Melhrotra, and C. Ray, Indian J. Exp. Biol. 6 (4), 232 (1968).

7. A. A. Baskar and S. Ignacimuthu, Exp. Toxicol. Pathol. 62 (4), 423 (2010). http://dx.doi.org/10.1016/j.etp.2009.06.003

8. S. Marappan and A. Subramaniyan, J. Adv. Sci. Res. 3 (1), 105 (2012).

9. S. Ahmed, M. S. Reza, and A. Jabbar, Fitoterapia 65, 463 (1994).

10. S. K. Singh, A. N. Kesari, R. K. Gupta, and G. J. Watal, J. Ethnopharmacol. 114 (2), 174 (2007). http://dx.doi.org/10.1016/j.jep.2007.07.039

11. K. Mangathayaru, M. Umadevi, and C. U. Reddy, J. Ethnopharmacol. 123 (1), 181 (2009).http://dx.doi.org/10.1016/j.jep.2009.02.036

12. C. Sadki, B. Hacht, A. Souliman, and F. Atmani, J. Ethnopharmacol. 128 (2), 352 (2010).http://dx.doi.org/10.1016/j.jep.2010.01.048

13. M. Najafi, H. Nazemiyeh, A. Garjani, H. Ghavimi, and A. Gharekhani. J. Mol. Cell Cardiol. 42 (1), S1(2007). http://dx.doi.org/10.1016/j.yjmcc.2007.03.035

14. M. N. Ghosh, Fundamentals of Experimental Pharmacology (Scientific Book Agency, Calcutta, 1984).

15. J. H. Burn, Practical Pharmacology (Blackwell Scientific Publications, Oxford, 1952).

16. M. M. Shabi, K. Gayathri, R. Venkatalakshmi, and C. Sasikala, Int. J. Chem.Tech. Res. 2.(1), 149 (2010).

17. H. Antoni and M. Rotmann, Pflugers Arch 67, 300 (1968).

18. D Garnier, J Nargeot, C Ojeda, and O Rougier, J. Physiol. 274, 381 (1978).

19. M. S. Amran, N. Homma, and K. Hashimoto. J. Sci. Res. 4 (1), 213 (2012). http://dx.doi.org/10.3329/jsr.v4i1.7722

20. P. F. Mery, L. Hove-Madsen, J. M. Chesnais, H. C. Hartzell, and R. Fischmeister, Am. J. Physiol. 270, 1178 (1996).

21. R. S. Furchgott, Annu. Rev. Pharmacol. Toxicol. 24, 175, (1984). http://dx.doi.org/10.1146/annurev.pa.24.040184.001135

22. T. M. Griffith, D. H. Edwards, M. J. Lewis, A. C. Newby and A. H. Henderson, Nature 308, 645 (1984). http://dx.doi.org/10.1038/308645a0 
23. S. Moncada, R. M. J. Palmer. and R. J. Gryglewski, Proc Natl Acad Sci 83, 9164 (1986). http://dx.doi.org/10.1073/pnas.83.23.9164

24. J. H. Adrian, F. T. John and G. Alan, Br. J. Pharmacol. 104, 645 (1991). PMid:1665746 PMCid:1908243

25. J. B. Richard, S. Maythem, and H. Andreas, J. Mol. Cell Cardiol. 19 (4), 343 (1987). http://dx.doi.org/10.1016/S0022-2828(87)80579-5

26. A. Gattuso, R. Mazza, D. Pellegrino and B. Tota, Am. J. Physiol. Heart Circ. Physiol. 276, 633 (1999).

27. R. A. Buccino, E. H. Sonnenblick, T. Cooper and E. Braunwald, Circ. Res. 19, 1097 (1966). PMid:5928546

28. R. J. S. McDowall, J. Physiol. (Lond.) 104, 392 (1946). PMCid:1393567

29. J. L. Amezcua, G. J. Dusting, R. M. J. Palmer, and S. Moncada, Br. J. Pharmacol. 95, 830 (1988). PMid:3061543 PMCid:1854237 